\title{
KAJIAN PENGGUNAAN BAHASA GURU SMA NEGERI 8 BENGKULU SELATAN TAHUN PELAJARAN 2011/2012
}

\author{
Sumarsih
}

\begin{abstract}
Penelitian ini bertujuan untuk mengdeskripsikan penggunaan bahasa Indonesia pada guru SMA Negeri 8 Bengkulu Selatan secara lisan pada saat proses belajar mengajar sesuai dengan faktafakta yang ditemukan di lapangan. Data pada penelitian ini dikumpulkan dengan teknik pengamatan dan rekaman. Data yang telah diperoleh dianalisis dengan langkah-langkah: (1) transkripsi data, (2) kodifikasi data, (3) klasifikasi data, (4) interpretasi data, (5) menarik keSimpulan. Temuan penelitian data menunjukkan bahwa bahasa yang digunakan guru SMA Negeri 8 Bengkulu Selatan adalah bahasa Indonesia dan bahasa Serawai. Bahasa yang digunakan ini mengandung fungsi personal atau pribadi, fungsi direktif, dan fungsi referensial. Tindak tutur yang diTemuankan meliputi tindak tutur representatif, tindak tutur direktif, tindak tutur ekspresif, dan tindak tutur interogatif.This research purpose was to describe the state of the usage of Indonesian at SMAN 8 South Bengkulu teacher verbally during the learning process in accordance with facts found in the field. Data collection in this research was done by observation and recording technique. Data which have been obtained were analysed with the steps: 1) data collecting, (2) transcription of data, (3) codification of data, (4) classification of data, (5) interpretation of data, (6) making concluding. The results of research show that the use of language teacher at SMAN 8 Bengkulu Selatan is Indonesian languages anda Serawai languages. This languages included personal function, directive function, and reference function. speech act which yielded included a representative speech act, directive speech act, expressive speech act, and interogative speech act.
\end{abstract}

Kata Kunci: penggunaan bahasa, fungsi bahasa, tindak tutur

\section{Pendahuluan}

Salah satu peran bahasa adalah sebagai bahasa pengantar di dunia pendidikan. Bahasa ini memiliki peranan yang sangat penting di dalam pengajaran di sekolah. Proses belajar mengajar di sekolah tak akan berjalan tanpa adanya bahasa. Hal ini sesuai dengan pendapat Suriamiharja (1984: 107) yang meyatakan bahwa bahasa dan pendidikan merupakan dua hal yang bertalian dengan eratnya. Bahasa adalah alat komunikasi dalam pendidikan, sedangkan pendidikan menyumbangkan sahamnya yang tak ternilai untuk mengembangkan dan membina bahasa.
Lingkungan sekolah merupakan sebuah masyarakat bahasa. Mengenai masyarakat bahasa ini Aslinda dan Syafyahya (2007: 8) menyatakan bahawa masyarakat bahasa merupakan sekelompok orang yang menggunakan bahasa yang sama dan sekelompok orang yang menggunakan bahasa yang berbeda dengan syarat di antara mereka terjadi saling pengertian. Dalam sebuah masyarakat bahasa dimungkinkan menggunakan lebih dari satu bahasa karena pada dasarnya setiap orang menguasai dan menggunakan lebih dari satu bahasa. 
Salah satu masyarakat bahasa yang jelas menggunakan dua bahasa atau lebih dalam proses belajar mengajarnya adalah SMA Negeri 8 Bengkulu Selatan. Siswa-siswa di sekolah ini berasal dari desa-desa yang ada di sekitar sekolah tersebut. Guru-guru yang mengajar di SMA ini pun, sebagian besar memang berasal dari daerah asli, yaitu Bengkulu Selatan dengan bahasanya bahasa Serawai.

Berdasarkan pengamatan yang penulis lakukan terhadap penggunaan bahasa Indonesia siswa, terlihat bahwa siswa merasa kesulitan menggunakan bahasa Indonesia, terutama untuk menulis dan berbicara. Penulis, sebagai guru bahasa Indonesia di SMA tersebut, mengalami kesulitan dalam mengajak siswa berbahasa Indonesia. Hal ini penulis asumsikan bahwa penyebabnya adalah jarangnya siswa mendengar bahasa Indonesia. Karena mereka jarang mendengarkan, maka mereka juga mengalami kesulitan menirukannya.

Sehubungan dengan bahasa yang dipakai dalam proses belajar mengajar ini, Chaer (2006:2) mengemukakan bahwa bahasa Indonesia memiliki peranan sebagai bahasa pengantar di dunia pendidikan. Sebagai bahasa pengantar di dunia pendidikan, bahasa Indonesia seyogyanya dipakai oleh guru dan siswa selama proses belajar mengajar di kelas.

Berdasarkan uraian di atas, maka penelitian ini berusaha untuk menjawab permasalahan-permasalahan:

(1) Bahasa apakah yang digunakan guru SMA Negeri 8 Bengkulu Selatan tahun pelajaran 2011/2012?

(2) Apakah fungsi-fungsi bahasa yang diTemuankan guru SMA Negeri 8
Bengkulu Selatan tahun pelajaran 2011/2012?

(3) Bagaimana bentuk tindak tutur guru di SMA Negeri 8 Bengkulu Selatan tahun pelajaran 2011/2012?

Tujuan dari penelitian ini adalah:

(1) Untuk mendeskripsikan bahasabahasa yang digunakan oleh guru SMA Negeri 8 Bengkulu Selatan tahun pelajaran 2011/2012?

(2) Untuk mendeskripsikan fungsi-fungsi bahasa yang diTemuankan guru SMA Negeri 8 Bengkulu Selatan tahun pelajaran 2011/2012?

(3) Untuk mendeskripsikan bentuk tindak tutur guru di SMA Negeri 8 Bengkulu Selatan tahun pelajaran 2011/2012.

Penelitian ini diharapkan dapat memberikan kontribusi terhadap penggunaan bahasa pada proses belajar mengajar pada khususnnya dan pada pengembangan kkurikulum pada umumnya.

\section{Metode Penelitian}

Metode yang digunakan dalam penelitian ini adalah metode deskriptif. Metode deskriptif digunakan dalam penelitian ini bertujuan untuk menggambarkan keadaan penggunaan bahasa Indonesia pada guru SMA Negeri 8 Bengkulu Selatan. Data penelitian tuturan guru pada saat kegiatan pembelajaran di kelas. Subjek penelitian ini adalah guru yang mengajar di SMA Negeri 8 Bengkulu Selatan, baik yang mengajar bidang studi IPA maupun IPS. Data ini dianalisis dengan prosedur sebagai berikut; (1) transkripsi data, (2) kodifikasi data, (3) klasifikasi data, (4) interpretasi dan (5) menyimpulkan. 
Temuan Penelitian dan Pembahasan

\section{1) Penggunaan Bahasa}

Telah dikatakan dalam Pendahuluan bahwa guru yang mengajar di SMA Negeri 8 Bengkulu Selatan, sebagian besar merupakan penduduk asli dari etnis Serawai, begitu juga dengan siswanya, maka dapat dikatakan bahwa guru dan siswa merupakan dwibahasawan, bahkan mungkin multibahasawan. Penutur dan mitra tutur merupakan dwibahasawan, maka dari Temuan penelitian ini diperoleh fakta bahwa selain bahasa Indonesia, bahasa daerah juga sering digunakan pada saat proses belajar mengajar, baik yang dilakukan oleh siswa maupun oleh guru. Hal ini tampak pada data berikut.

\section{1/FIS/13-08-2011/SMA8/XI IPA2}

Guru : $\alpha(7 a)$. Jadi, itu perbedaannya(7b). Kalau cara mencarinya itu tetap sama(7c). Jadi samo ajo 'sama saja' kalau ndalaki dio 'mencarinya' (7d). Kalau masih pakai turunan, masih tetap pakai turunan (7e).

Dari data tersebut tampak bahwa bahasa Serawai digunakan oleh guru dan siswa pada saat proses belajar mengajar untuk menggantikan bahasa Indonesia. Kata-kata yang telah diucapkan oleh guru (sebagai penutur) dalam bahasa Indonesia diulang dengan makna yang sama dalam bahasa Serawai. Siswa pun (mitra tutur) menjawab dengan menggunakan bahasa Serawai.

Dari data yang terkumpul terlihat bahwa pada saat proses belajar mengajar sering terjadi alih kode dan campur kode. Seperti apa yang disampaikan oleh Chaer dan Agustina bahwa peristiwa ini terjadi oleh beberapa sebab. Peristiwa alih kode dan campur kode serta hal-hal yang menjadi penyebabnya akan dibahas sebagai berikut.

\section{(a) Alih Kode (Code Switching)}

Dari penelitian yang telah dilakukan diperoleh data bahwa terjadi alih kode dalam peristiwa tutur pada saat proses belajar mengajar. Alih kode ini adalah penggunaan dua bahasa atau lebih secara bergantian pada satu kondisi. Pada penelitian ini, alih kode terjadi antara bahasa Indonesia dan bahasa Serawai yang dipakai secara bergantian pada saat proses belajar mengajar. Alih kode ini dapat terlihat dari data berikut.

\section{1/FIS/13-08-2011/SMA8/XI IPA2}

Guru : Nah, setelah dihidupkan dan berjalan, kenapa motor itu berjalan? (13e) Karno apo? 'karena apa?'(13f)

Dari data tersebut tampak bahwa terjadi alih kode yang dilakukan oleh guru pada saat proses belajar mengajar. Pada kondisi di atas, ketika guru menjelaskan tentang kecepatan dan percepatan, guru menanyakan sebabsebab mengapa sepeda motor dapat berjalan. Ketika itu guru menggambarkan kondisi sepeda motor setelah dihidupkan dan menanyakan mengapa sepeda motor tersebut dapat berjalan. Pertanyaan tersebut kemudian diulang dengan menggunakan bahasa Serawai. Kata-kata yang tercetak miring merupakan kata-kata dalam bahasa Serawai, sedangkan kata-kata yang tercetak tegak merupakan kata-kata bahasa Indonesia.

\section{(b) Campur Kode (Code Mixing)}

Selain alih kode, hal yang terjadi pada saat proses belajar mengajar dengan guru seorang dwibahasawan 
adalah adanya campur kode (code mixing). Data yang diperoleh dari penelitian ini, juga terjadi campur kode pada saat proses belajar mengajar di SMA Negeri 8 Bengkulu Selatan.

Data itu dapat dilihat sebagai berikut.

\section{1/FIS/13-08-2011/SMA8/XI IPA2}

Guru : Kalau ndek dio 'tidak ada' kita lanjutkan dengan percepatan (38a). Kalau kemarin rumus kecepatan apa? (38b)

02/PKn/12-08-2011/SMA8/XI IPA 1

Guru : Nah, segalo 'semua' wong cilik dilupakan. (29e)

Dari data tersebut terlihat bahwa terjadi campur kode pada saat proses belajar mengajar. Guru menyelipkan kata-kata bahasa Serawai di antara kata-kata bahasa Indonesia yang dipakai. Kata yang tercetak miring pada data di atas merupakan kata-kata bahasa Serawai, sedangkan kata yang lainnya adalah kata-kata bahasa Indonesia.

\section{1) Fungsi Bahasa}

Berdasarkan penelitian yang telah dilakukan diperoleh Temuan bahwa bahasa yang digunakan oleh guru SMA Negeri 8 Bengkulu Selatan tahun pelajaran 2011/2012 mengandung fungsi-fungsi sebagai berikut.

\section{(a) Fungsi Personal atau pribadi}

Dari penelitian yang telah dilakukan diperoleh Temuan bahwa bahasa yang digunakan oleh guru SMA Negeri 8 Bengkulu Selatan tahun pelajaran 2011/2012 berfungsi untuk menyatakan sikap terhadap apa yang dituturkannya. Data yang menunjukkan fungsi ini adalah sebagai berikut.
02/PKn/12-08-2011/SMA8/XI IPA 1

Guru : Keruan tugasnya apo? 'tahu tugasnya apa?'(43a) Kebiasaan kamu Harisman ndek berubah 'tidak berubah'. (43b)

Data di atas memperlihatkan bahwa bahasa ini berfungsi untuk menyatakan sikap pembicara. Melalui tuturan tersebut penutur ingin menyatakan bahwa penutur sedang marah kepada mitra tutur karena mitra tutur memiliki kebiasaan yang kurang baik, yaitu tidak memperhatikan ketika penutur sedang berbicara.

\section{(b) Fungsi Direktif}

Berdasarkan data yang terkumpul, penggunaan bahasa guru SMA Negeri 8 Bengkulu Selatan juga berfungsi untuk mengatur tingkah laku mitra tutur. Penutur mengharapkan mitra tutur mau melakukan kegiatan yang sesuai dengan keinginan penutur. Hal ini tampak pada data berikut.

01/FIS/13-08-2011/SMA8/XI IPA2

Guru : Kito mbak kini ndek 'kita sekarang tidak' bicara masalah mesin (15a). Lah keruan galo dengan kito baso motor itu bemesin 'kita sudah tahu semua bahwa motor itu bermesin' (15b).

Dari data di atas terlihat bahwa kata-kata itu bukan hanya berupa pernyataan, tetapi secara tidak langsung penutur memerintahkan mitra tutur untuk berpikir hal lain yang menyebabkan sebuah sepeda motor dapat berjalan. Penutur mengatakan bahwa saat ini tidak berbicara mengenai mesin dan semua sudah mengetahui bahwa motor bermesin. Penutur menginginkan mitra tutur bepikir tentang hal yang berbeda yang menjadi penyebab berjalannya sepeda motor. 


\section{(c) Fungsi Referensial}

Bahasa yang digunakan oleh guru SMA Negeri 8 Bengkulu Selatan berfungsi juga untuk membicarakan objek atau peristiwa yang ada di sekitar penutur. Fungsi ini dapat dilihat dari data berikut.

\section{1/FIS/13-08-2011/SMA8/XI IPA2}

Guru : Kalau pada gerak lurus posisi itu dilambangkan dengan $\mathrm{R}$ sedangkan untuk gerak melingkar posisi itu dilambangkan dengan $\theta(1 \mathrm{e})$.

Dari data di atas terlihat bahwa bahasa itu berfungsi untuk membicarakan sebuah objek. Objek yang dibicarakan pada tuturan tersebut adalah lambang posisi pada gerak. Tujuan dari tuturan ini adalah supaya mitra tutur memahami apa yang disampaikan oleh penutur.

\section{1) Tindak Tutur (Speech Act)}

Berdasarkan penelitian yang penulis lakukan pada guru yang mengajar bahwa bahasa yang dipakai oleh guru-guru di SMA dalam menyampaikan materi pelajaran mengandung tindak tutur representatif, tindak tutur direktif, tindak tutur ekspresif, dan tindak tutur interogatif. Masing-masing tindak tutur tersebut akan dideskripsikan sebagai berikut.

\section{a. Tindak Tutur Representatif}

Sesuai penelitian yang telah dilakukan, diperoleh data bahwa tindak tutur representatif yang diTemuankan oleh guru yang mengajar di SMA Negeri 8 Bengkulu Selatan meliputi tindak tutur yang menyatakan menunjukkan, mengemukakan, dan menjelaskan.

Tindak tutur yang menyatakan menunjukkan diTemuankan oleh guru ketika guru ingin menunjukkan sesuatu sebagai pelengkap dalam menjelaskan materi pelajaran kepada siswa. Hal ini dimaksudkan supaya siswa lebih mudah memahami penjelasan yang diberikan. Tindak tutur ini dapat dilihat dari data sebagai berikut.

\section{1/FIS/13-08-2011/SMA8/XI IPA2}

Guru :Jadi, itu perbedaannya(7b). Kalau cara mencarinya itu tetap sama. (7c). Jadi, samo ajo 'sama saja' kalau ndalaki dio 'mencarinya' (7d).

02/PKn/12-08-2011/SMA8/XI IPA 1

Guru : Banyak sekali perbedaan. (13d) Diekspresikan seperti kalau kita ingin menghadap penguasa atau orang yang mempunyai kekuasaan itu memiliki cara-cara tertentu. (13e)

Dari data tersebut dapat kita lihat salah satu bentuk tindak tutur yang mengandung makna menunjukkan. Ciri linguistik dari makna menunjukkan ini sama dengan makna berita, yaitu bila dilisankan diakhiri dengan nada yang menurun dan jika dituliskan diakhiri dengan tanda titik.

Tindak tutur representatif selanjutnya adalah tindak tutur yang mengandung makna mengemukakan. Tindak tutur ini diTemuankan oleh guru ketika guru mengemukakan sesuatu kepada siswa. Hal ini dapat dilihat dari data berikut.

01/FIS/13-08-2011/SMA8/XI IPA2

Guru : Yang pakai motor takut ditanyoi 'ditanyai'. (13a).

02/PKn/12-08-2011/SMA8/XI IPA 1

Guru : Ibu ada tugas. (41a) (diam sejenak) Ibu semalam mulai ibu tulis. (41b) 
Dari data tersebut terlihat guru mengemukakan bahwa yang memakai motor takut diberi pertanyaan. Pertanyaan tersebut berhubungan dengan materi pelajaran, sehingga siswa khawatir jika dia menjawab pertanyaan dari guru maka akan diberi pertanyaan lebih lanjut. Data berikutnya guru mengemukakan bahwa guru akan memberikan tugas kepada siswa.

Ciri linguistik dari tindak tutur yang mengandung makna mengemukakan ini adalah jika dilisankan, tindak tutur ini diakhiri dengan nada menurun, jika dituliskan akan diakhiri dengan tanda titik.

Tindak tutur representatif berikutnya yang ditemukan dalam penelitian adalah tindak tutur yang mengandung makna menjelaskan. Tindak tutur ini diTemuankan oleh guru ketika guru memberikan penjelasan kepada siswa tentang materi yang sedang diajarkan. Reaksi yang diinginkan oleh guru sebagai penutur terhadap siswa sebagai mitra tutur adalah siswa dapat menangkap apa yang disampaikan oleh guru. Ciri linguistiknya adalah jika dilisankan akan diakhiri dengan nada yang menurun, dan jika dituliskan akan diakhiri dengan tanda titik. Hal ini dapat dilihat dari data berikut.

\section{1/FIS/13-08-2011/SMA8/XI IPA2}

Guru :Jadi, untuk posisi pada gerak lurus itu hampir sama dengan posisi pada gerak (berhenti sejenak) melingkar(1b). Yang membedakan di sini itu cuman ... (diam sejenak) satuan dan tanda(1c).

Dari data di atas terlihat bahwa tindak tutur ini diTemuankan oleh guru untuk menjelaskan materi tentang posisi gerak lurus dan posisi pada gerak melingkar. Ini dikemukakan supaya siswa dapat memahami materi tentang posisi pada gerak lurus dan posisi pada gerak melingkar.

Ciri linguistik dari tindak tutur ini adalah jika dilisankan akan diakhiri dengan nada yang menurun dan jika dituliskan akan diakhiri dengan tanda titik. Data dari tindak tutur ini dapat dilihat berikut.

\section{1/FIS/13-08-2011/SMA8/XI IPA2 \\ Guru : Jadi percepatan itu adalah perubahan kecepatan. ... ditambah dikit ... terhadap waktu ... terhadap waktu (36c). Perubahan kecepatan terhadap waktu. (36d)}

Dari data di atas terlihat juga bahwa tindak tutur ini diTemuankan oleh guru untuk menjelaskan materi tentang percepatan. Guru sebagai penutur berharap siswa sebagai mitra tutur memahami apa yang disampaikannya. Ciri linguistik dari tindak tutur ini adalah jika dilisankan akan diakhiri dengan intonasi yang menurun dan jika dituliskan akan diakhiri dengan tanda titik (.).

\section{b) Tindak tutur Direktif}

Tindak tutur direktif ini secara umum diTemuankan oleh guru untuk mendorong mitra tutur (siswa) melakukan sesuatu. Tindak tutur direktif ini oleh Rahardi disebut dengan tindak tutur imperatif. Menurut Austin, tindak tutur ini meliputi mengusulkan, memohon, meminta, dan memerintah. Berdasarkan penelitian yang dilakukan, diperoleh data bahwa tindak tutur direktif yang diTemuankan oleh guru di SMA Negeri 8 Bengkulu Selatan meliputi tindak tutur yang bermakna menyuruh, 
meminta dan mengajak. Masing-masing tindak tutur ini akan dijelaskan berikut beserta contoh datanya.

Tindak tutur direktif yang pertama yang diTemuankan oleh guru sebagai penutur adalah tindak tutur yang menyatakan menyuruh. Tindak tutur ini berupa suruhan yang mengharapkan suatu tindakan dari mitra tutur untuk mengikuti apa yang diinginkan oleh penutur. Data mengenai tindak tutur ini dapat dilihat berikut.

\section{1/FIS/13-08-2011/SMA8/XI IPA2}

Guru : Silakan dicatat sendiri! (36b)

02/PKn/12-08-2011/SMA8/XI IPA 1

Guru : Sebelumnya, Yuldi, maju! (1b) Maju!(1c) Ha.. Nopan, maju!(1d) Amalia, maju Amalia!(1e) Dengan ... Juni, maju sini!(1f) Yuldi, Nopan, Amalia, Juni, maju!(1g) Yuldi!(1h) Amalia, maju selangkah!(1i)

Dari data di atas terlihat bahwa tindak tutur ini bermakna menyuruh siswa. Guru menyuruh siswa untuk mencatat materi yang telah dijelaskan. Harapan guru sebagai penutur adalah supaya siswa sebagai mitra tutur mengikuti apa yang diinginkan oleh guru, yaitu mencatat materi pelajaran.

Data berikutnya, tindak tutur ini bermakna menyuruh siswa. Guru menyuruh siswa untuk maju ke depan kelas. Harapannya adalah supaya siswa mengikuti apa yang diinginkan oleh penutur, yaitu maju ke depan kelas.

Ciri linguistik dari tindak tutur ini adalah diawali dengan kata silakan. Ciri lain adalah jika dilisankan maka diakhiri dengan nada yang sedikit meninggi, namun jika dituliskan maka akan diakhiri dengan tanda seru (!).
Tindak tutur direktif selanjutnya yang diTemuankan oleh guru adalah tindak tutur yang bermakna meminta. Tindak tutur ini diungkapkan oleh guru untuk meminta kepada siswa supaya siswa melakukan sesuatu sesuai dengan apa yang diminta oleh guru. Data mengenai tindak tutur itu dapat dilihat sebagai berikut.

\section{1/FIS/13-08-2011/SMA8/XI IPA2}

Guru : Cubo kinaki kudai ' coba lihat dulu' di motor! (21a)

Dari data di atas terlihat bahwa tindak tutur ini bermakna meminta. Guru meminta siswa untuk melihat tanda apa yang ada di motor. Reaksi yang diinginkan oleh guru sebagai penutur adalah siswa mau melihat tanda apa yang ada di motor. Tanda itu akan berguna bagi pembelajaran tersebut.

Ciri linguistik dari tindak tutur ini adalah diawali dengan kata cubo 'coba'. Ciri lain adalah jika dilisankan tindak tutur ini diakhiri dengan nada yang sedikit meninggi, namun jika dituliskan tindak tutur ini diakhiri dengan tanda seru (!).

Tindak tutur direktif yang terakhir yang diTemuankan oleh guru SMA Negeri 8 Bengkulu Selatan adalah tindak tutur yang mengandung makna mengajak. Tindak tutur ini diungkapkan oleh guru untuk mengajak siswa melakukan sesuatu. Harapan guru sebagai penutur adalah siswa sebagai mitra tutur mau melakukan sesuatu. Tindak tutur ini dapat dilihat dari data berikut.

01/FIS/13-08-2011/SMA8/XI IPA2

Guru : Jadi, kita lanjutkan! (1a)

Dari data di atas terlihat bahwa tindak tutur ini bermakna mengajak. Guru mengajak siswa untuk melanjutkan 
materi yang sedang dibahas. Reaksi yang diinginkan guru dari siswa adalah siswa mau memperhatikan penjelasan berikutnya. Penjelasan yang akan disampaikan oleh guru merupakan penjelasan lanjutan dari penjelasanpenjelasan sebelumnya.

Ciri linguistik dari tindak tutur ini adalah jika dilisankan tindak tutur ini diakhiri dengan nada yang agak meninggi dan jika dituliskan maka diakhiri dengan tanda titik.

\section{c) Tindak Tutur Ekspresif}

$$
\text { Berdasarkan }
$$

penelitian

diperoleh Temuan bahwa tindak tutur ekspresif yang diTemuankan oleh guru SMA Negeri 8 Bengkulu Selatan adalah tindak tutur yang menyatakan membenarkan dan menyalahkan secara halus. Masing-masing tindak tutur akan dijelaskan sebagai berikut beserta contoh datanya.

Tindak tutur ekspresif yang pertama yang diTemuankan oleh guru SMA Negeri 8 Bengkulu Selatan adalah tindak tutur yang bermakna membenarkan. Tindak tutur ini dapat dilihat dari data berikut.

\section{1/FIS/13-08-2011/SMA8/XI IPA2}

Guru : Benar ada perpindahan (16f).

Dari data di atas terlihat bahwa guru membenarkan apa yang disampaikan oleh siswa. Pembenaran ini disampaikan karena siswa menjawab pertanyaan guru dengan benar.

Ciri linguistik dari tindak tutur ini adalah adanya kata benar. Dengan adanya kata benar ini secara langsung guru telah menyatakan bahwa apa yang disampaikan siswa tersebut benar. Ciri linguistik lain dari tindak tutur ini adalah jika dilisankan maka diakhiri dengan nada yang sedikit merendah dan jika dituliskan akan diakhiri dengan tanda seru (!).

Tindak tutur ekspresif berikutnya yang diTemuankan soleh guru SMA Negeri 8 Bengkulu Selatan adalah tindak tutur yang bermakna menyalahkan. Tindak tutur ini disampaikan oleh guru karena guru merasa tidak puas dengan apa yang dilakukan oleh guru. Tindak tutur ini dapat dilihat dari data berikut.

\section{1/FIS/13-08-2011/SMA8/XI IPA2}

Guru : Awak pakai motor terus tiap haRi 'hari'! (26a) Percepatan ndek keruan 'tidak tahu', kecepatan ndek keruan 'tidak tahu'! (26b)

Dari data di atas terlihat bahwa terlihat bahwa tindak tutur yang diTemuankan oleh guru ini adalah menyalahkan secara halus. Guru secara halus menyalahkan siswa karena siswa tidak memahami kecepatan dan percepatan walaupun setiap hari menggunakan motor. Menurut asumsi guru, siswa seharusnya mengetahui percepatan dan kecepatan karena mereka setiap hari menggunakan motor. Pada pemakaian sepeda motor terdapat kecepatan dan percepatan.

Ciri linguistik dari tindak tutur ini adalah jika dilisankan tindak tutur ini diawali dengan intonasi yang sedikit meninggi dan diakhiri dengan intonasi yang merendah. Namun, jika dituliskan tindak tutur ini diakhiri tanda seru (!).

\section{d) Tindak Tutur Interogatif}

Dari penelitian di SMA Negeri 8 Bengkulu Selatan diperoleh data bahwa tindak tutur interogatif yang diTemuankan oleh guru meliputi tindak tutur interogatif yang memang menginginkan jawaban dan tindak tutur 
interogatif yang tidak menginginkan jawaban. Masing-masing tindak tutur interogatif ini akan dibahas sebagai berikut beserta contohnya datanya.

Tindak tutur interogatif yang pertama adalah tindak tutur interogatif yang memerlukan jawaban. Pertanyaan yang disampaikan oleh penutur benarbenar menginginkan jawaban dari mitra tutur. Hal ini terlihat dari data berikut.

\section{1/FIS/13-08-2011/SMA8/XI IPA2}

Guru :Apakah selama kalian pakai motor itu kecepatannya selalu seperti itu?

Dari data di atas terlihat bahwa tindak tutur interogatif tersebut benarbenar membutuhkan jawaban dari miitra tutur. Penutur menanyakan apakah kecepatannya selalu sama selama siswa (mitra tutur) mengendarai sepeda motor. Tindak tutur ini menginginkan jawaban dari mitra tutur. Jawaban yang diinginkan adalah 'ya' atau 'tidak'.

Ciri linguistik dari tindak tutur ini adalah jika dilisankan akan diakhiri dengan intonasi yang meninggi. Ciri lainnya adalah jika dituliskan, tindak tutur ini menggunakan kata tanya 'apakah' dan diakhiri dengan tanda tanya (?).

Tindak tutur interogatif yang kedua adalah tindak tutur interogatif yang tidak menginginkan jawaban. Tindak tutur ini disampaikan oleh penutur dimaksudkan untuk menarik perhatian mitra tutur, bukan untuk mencari jawaban. Tindak tutur ini dapat dilihat dari data berikut.

\section{2/PKn/12-08-2011/SMA8/XI IPA 1}

Guru : Sangat apa? (13c) Banyak sekali perbedaan. (13d)
Dari data di atas terlihat bahwa tindak tutur ini disampaikan oleh penutur hanya untuk menarik perhatian mitra tutur. Penutur tidak menginginkan jawaban dari mitra tutur karena jawabannya langsung disampaikan oleh penutur.

Ciri linguistik dari tindak tutur ini sama dengan tindak tutur interogatif yang lain, yaitu jika dilisankan diakhiri dengan intonasi yang meninggi, namun jika dituliskan tindak tutur ini menggunakan kata tanya 'apa' dan diakhiri dengan tanda tanya (?). Hanya bedanya dengan tindak tutur lainnya adalah bahwa tindak tutur ini dilanjutkan dengan jawaban yang diinginkan. Jawaban ini disampaikan sendiri oleh mitra tutur, sehingga tidak perlu menunggu jawaban dari mirta tutur.

\section{Simpulan}

Dari penelitian yang telah dilakukan dapat disimpulkan bahwa. Bahasa yang digunakan oleh guru yang mengajar di SMA Negeri 8 Bengkulu Selatan tahun ajaran 2011/2012 yaitu bahasa Indonesia dan bahasa Serawai. Bahasa tersebut memiliki fungsi fungsi personal, fungsi direktif, fungsi referensial. Tindak tutur yang diTemuankan oleh guru yang mengajar di SMA Negeri 8 Bengkulu Selatan tahun ajaran 2011/2012 meliputi 4 (empat) tindak tutur, yaitu tindak tutur representatif, tindak tutur direktif, tindak tutur ekspresif, dan tindak tutur interogatif. Namun, yang paling banyak diTemuankan adalah tindak tutur representatif.

\section{Saran}

Sebagai seorang guru yang mengajar di pendidikan tingkat 
menengah atas, hendaknya guru menerapkan fungsi bahasa Indonesia sebagai bahasa resmi atau bahasa pengantar di dunia pendidikan. Guru hendaknya menggunakan bahasa Indonesia secara tertib selama proses belajar mengajar. Guru hendaknya meminimalisai penggunaan bahasa daerah dan menggunakan bahasa Indonesia sepenuhnya selama proses belajar mengajar. Dengan demikian, siswa pun akan ikut tertib menggunakan bahasa Indonesia.

\section{Daftar Pustaka}

Aslinda dan Leni Syafyahya. 2007. Pengantar Sosiolinguistik. Bandung: Refika Aditama

Chaer, Abdul dan Agustina, Leonie. 2004. Sosiolinguistik. Jakarta: Rineka Cipta

Chaer, Abdul. 2006. Tata Bahasa Praktis Bahasa Indonesia. Jakarta: PT Rineka Cipta
Furchan, Arief. 1982. Pengantar Penelitian dalam Pendidikan. Surabaya:Usaha Nasional

Ibrahim, Abd. Syukur. 1995. Sosiolinguistik Sajian, Tujuan, Pendekatan, dan Problem. Surabaya: Usaha Nasional

Rahardi, R. Kunjana. 2004. Berkenalan dengan IImu Bahasa Pragmatik. Malang: Dioma

Rahardi, R. Kunjana. 2005. Pragmatik Kesantunan Imperatif Bahasa Indonesia. Jakarta: Erlangga

Rustono. 1999. Pokok-pokok Pragmatik. Semarang: Semarang Press

Sumarsono dan Paina Partana. 2002. Sosiolinguistik.Yogyakarta: Sabda

Suryaman, Ukun. 1992. Dasar-Dasar Bahasa Indonesia Baku. Bandung: Alumni 